\title{
A rare cause of acute abdomen: spontaneous common hepatic duct perforation
}

\author{
Hüseyin Pülat, M.D., ${ }^{1}$ Oktay Karaköse, M.D., ${ }^{1}$ Mehmet Fatih Benzin, M.D., ${ }^{2}$ \\ Mehmet Zafer Sabuncuoğlu, M.D., ${ }^{2}$ Recep Çetin, M.D. ${ }^{1}$
}

${ }^{1}$ Department of Surgical Oncology, Suleyman Demirel University Faculty of Medicine, Isparta, Turkey

${ }^{2}$ Department of General Surgery, Suleyman Demirel University Faculty of Medicine, Isparta, Turkey

\begin{abstract}
Spontaneous extrahepatic bile duct perforation is generally seen in infants. Although rarely seen in adults, it may be seen with fatal bile peritonitis. Therefore, for a patient presenting with acute abdominal symptoms, differential diagnosis must be made with radiological imaging such as abdominal ultrasonography or computed tomography, without any loss of time. In these imaging tests, in cases of gallstone disease together with perihepatic free fluid or choledocus which can not be monitored, it should be considered in the differential diagnosis. An emergency surgical intervention should be planned to avoid serious complications. The aim of this paper was to present the rare cause of acute abdomen which developed associated with spontaneous common hepatic canal perforation in an adult.
\end{abstract}

Keywords: Acute abdomen; common hepatic duct; spontaneous perforation; surgery.

\section{INTRODUCTION}

Spontaneous extrahepatic bile duct perforation (SEBDP) is an extremely rarely seen cause of acute abdomen in adults. ${ }^{[1]}$ Preoperative diagnosis is very difficult, and diagnosis is often made during surgery. ${ }^{[2]}$ However, with the use of abdominal ultrasonography (US) together with multidetector computed tomography (CT), preoperative diagnosis can be made. Although the most common location is the choledocus, hepatic canal damage may also be seen. ${ }^{[3]}$ In cases of gallstone disease, simple peritoneal drainage, cholecystectomy and T-tube drainage are effective and safe treatment choices. ${ }^{[2]}$ In these patients, fatal complications can be avoided with early diagnosis and treatment.

\section{CASE REPORT}

A 36-year-old female had been admitted to our clinic 15 days previously with a diagnosis of biliary oedematous pancreatitis

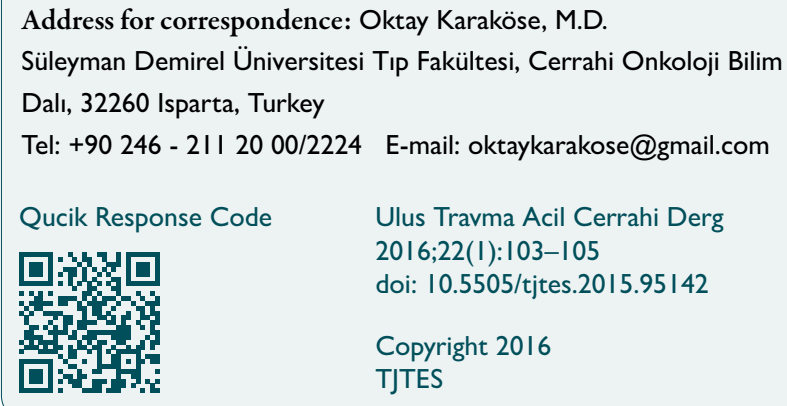

(Fig. Ia), and with clinical recovery after medical treatment, she was discharged after 8 days. She presented again with complaints of sudden onset back and abdominal pain, nausea and bilious vomiting. On physical examination, the abdomen was distended with widespread sensitivity, defence and rebound. Murphy's sign was positive. Intestinal sounds were reduced with auscultation. Vital signs included abody temperature of $38.5^{\circ} \mathrm{C}$, pulse of $110 /$ minute, and an arterial blood pressure of $100 / 60 \mathrm{mmHg}$. Laboratory test results were determined high with leukocytes $16 \times 10^{3} / \mathrm{uL}$ (5.2-12.4), CRP $132 \mathrm{mg} / \mathrm{l}$ (0-10), amylase $230 \mathrm{U} / \mathrm{L}$ (28-100), lipase $205 \mathrm{U} / \mathrm{L}$ (2I-67), alkaline phosphatase $674 \mathrm{U} / \mathrm{L}$ (30-120), LDH 268 $\mathrm{U} / \mathrm{L}(0-247)$, total bilirubin $1.38 \mathrm{mg} / \mathrm{dL}(0.3-1.2)$ and direct bilirubin $0.5 \mathrm{I} \mathrm{mg/dL} \mathrm{(0-0.2).} \mathrm{On} \mathrm{abdominal} \mathrm{US,} \mathrm{intrahepatic}$ bile ducts were evident in the centre, the gallbladder wall thickness was seen to have slightly increased, and there was an appearance of many stones within the lumen. Free fluid was observed in the perihepatic and perisplenic areas and between the intestinal ans. On abdominal CT, a fluid collection approximately I Ix42×76 mm with multiple lobular contours was seen in the upper right quadrant adjacent to the inferior liver and extending to adjacent to the head of the pancreas and compressing on the duodenum, and free fluid within the abdomen and pelvic area contaminating the mesenteric tissues was determined (Fig. Ib). The thickness of the gallbladder wall had increased. The bile duct perforation was thought to have occurred as the choledocus could not be monitored because of the adjacent fluid. In this patient who had previously experenced pancreatitis, an area was determined within 

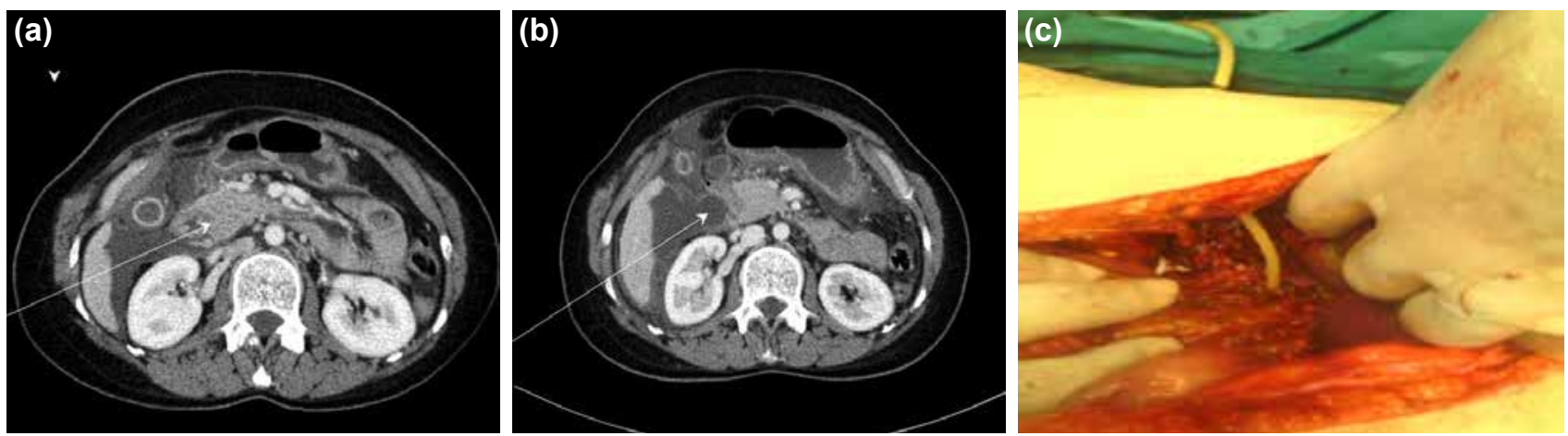

Figure 1. (a) Axial coronal CT scan of the abdomen showing edematous and inflamed head of pancreas and collection of peripancreatic fluid. (b) Axial coronal CT scan of the abdomen showing compressing the duodenum and multiple lobulated collection of fluid. (c) Intraoperative appearance of $\mathrm{T}$ - tube in the perforation area.

the pancreas parenchyma consistent with ischaemia or necrosis.

The patient was admitted for surgery with an initial diagnosis of bile duct perforation. In the exploration, there was widespread bile within the abdomen. Following dissection of adhesions in the subhepatic area, it was seen that the hydropic and wall thickness of the gallbladder had increased. Millimetric stones were palpated in the gallbladder neck. In the continuation of the exploration, a $2 \mathrm{~cm}$ ischaemic area was determined in the anterior of the common hepatic canal and it was here that the perforation had occurred (Fig. Ic). There was slight oedema of the head of the pancreas, but no haemorrhagic or necrotising appearance in the pancreas. After cleaning within the abdomen, and cholecystectomy, the distal choledocus and proximal bile ducts were checked with choleducus coils. As no additional pathology, such as choledocus stone, papillary stenosis or choledocal cyst was determined, a T-tube drain was placed from the perforation area to the common hepatic canal and the operation was terminated. On the postoperative twenty-first day, the passage to the duodenum was seen to be normal on cholangiography applied from the T-tube, and the T-tube was removed. Pathological examination of cholecystectomy determined ulcerous cholesistitis and cholelithiasis. During a one-year follow-up period, no complications were seen.

\section{DISCUSSION}

In the majority of SEBDP cases, perforation location is determined at the conjunction of the cystic canal with choledocus. ${ }^{[4,5]}$ Very few cases have been reported in the common hepatic cannal, especially in adults. ${ }^{[3]}$ As it is rarely seen, prevalence, morbidity and mortality rates are not certain. However, when diagnosis is delayed, fatal bile peritonitis may develop. [6,7] While $80 \%$ of cases with SEBDP are seen to be clinically subacute, acute abdominal findings occur in the remainder. [5,8] The case presented here had findings of acute abdomen.

In adults, the etiological factors held responsible are viral infections, stone and/or erosion caused by a stone, biliary sludge, congenital weakness of the wall because of a con- nective tissue defect, bile canal ischaemia, intramural infection, cyst or diverticulum and pancreas fluid reflux. ${ }^{[9,10]}$ In the current case, there were many millimetric stones within the gallbladder lumen. However, they were not of a size to create pressure on the extrahepatic bile ducts. In the extrahepatic bile ducts, no gallstones, sludge or sphincter which would increase pressure in the lumen were determined. However, the wall of the common hepatic canal was extremely thin and weak in structure. As the patient had recently had pancreatitis, the etiological reasons could be considered to be pancreatic fluid reflux, wall weakness and stones in the gallbladder lumen determined in the operation and necrosis of the common hepatic canal.

Advanced methods such as scintigraphy and choledoscopy can be useful in preoperative diagnosis but are difficult to apply under emergency conditions. ${ }^{[I]}$ Even though it is said in the literature that generally radiological imaging methods such as abdominal US and CT are insufficient for preoperative diagnosis, ${ }^{[l]}$ after careful examination of these tests, bile duct perforation can be determined. Therefore, in patients presenting with acute abdomen, SEBDP should be considered in the differential diagnosis in cases of gallstone disease determined together with perihepatic free fluid or peritonitis or when the chholedocus can not be monitored.

In the treatment of SEBDP, there are choices such as symptomatic, medical, interventional, and surgical methods. ${ }^{[I]}$ From surgical treatment choices, the most frequently recommended ones are simple peritoneal drainage when it is seen that there is no obstruction in the distal, and T-tube drainage applied to the perforation area together with cholecystectomy. ${ }^{[2]}$ The T-tube should be removed after remaining in place for free drainage for up to two-three weeks. ${ }^{[5]}$ In the case presented here, no problems were experienced during drainage or after removing the T-tube.

Possible complications of SEBDP are cholangitis, portal vein thrombosis and bile leakage. ${ }^{[8,12]}$ However, with early diagnosis and appropriate surgical intervention as in the current case, the frequency of complications is reduced. 
In conclusion, in a patient with a recent history of pancreaticobiliary pathology presenting with acute abdomen, abdominal US and multidetector CT must be taken without losing any time. In cases of gallstone pathology and determination of pericholecystic, perihepatic free fluid and when the choledocus can not be monitored on these imaging tests, extrahepatic bile duct perforation should be considered in the differential diagnosis. Emergency surgery must be planned in the shortest time possible to reduce and protect against complications.

Conflict of interest: None declared.

\section{REFERENCES}

1. Çeleb F, Balık AA, Yıldırgan Mİ, Demirci N, Ören D. Spontaneous perforation of the choledoc (Case report). T Klin J Med Sci 2002;22:56-8.

2. Sözütek A, Karabuğa T, Derici $H$, Bozdağ AD. A rare cause of acute abdomen: spontaneous choledochus perforation. Akademik gastroenteroloji dergisi 2010;9:32-3.

3. Sert İ, Salimoğlu S. Spontaneous perforation of the left hepatic duct: Case report. Turkiye Klinikleri J Case Rep 2013;21:53-5.
4. Sen M, Turan M, Kurt A, Er Y. Spontaneous perforation of the ductus choledochus: case report. Cumhuriyet Med J 2009;31:75-7.

5. Ozdemir T, Akgül AK, Arpaz Y, Arikan A. Spontaneous bile duct perforation: a rare cause of acute abdominal pain during childhood. [Article in Turkish] Ulus Travma Acil Cerrahi Derg 2008;14:211-5.

6. Rege SA, Lambe S, Sethi H, Gandhi A, Rohondia O. Spontaneous common bile duct perforation in adult: a case report and review. Int Surg 2002;87:81-2.

7. Aydin U, Yazici P, Coker A. Spontaneous rupture of intrahepatic biliary ducts with biliary peritonitis. Indian J Gastroenterol 2007;26:188-9.

8. Imanieh MH, Mowla A, Zohouri D, Forootan HR, Karimi M. Spontaneous perforation of the common bile duct with eosinophilia in an 18-month-old girl: a case report and review of literature. Med Sci Monit 2006;12:CS31-3.

9. Kang SB, Han HS, Min SK, Lee HK. Nontraumatic perforation of the bile duct in adults. Arch Surg 2004;139:1083-7.

10. Megison SM, Votteler TP. Management of common bile duct obstruction associated with spontaneous perforation of the biliary tree. Surgery 1992;111:237-9.

11. Fitzgerald RJ, Parbhoo K, Guiney EJ. Spontaneous perforation of bile ducts in neonates. Surgery 1978;83:303-5.

12. Evans K, Marsden N, Desai A. Spontaneous perforation of the bile duct in infancy and childhood: a systematic review. J Pediatr Gastroenterol Nutr 2010;50:677-81.

\section{OLGU SUNUMU - ÖZET}

\section{Nadir bir akut karın nedeni: Spontan ortak hepatik kanal perforasyonu}

Dr. Hüseyin Pülat, ${ }^{1}$ Dr. Oktay Karaköse, ${ }^{1}$ Dr. Mehmet Fatih Benzin, ${ }^{2}$ Dr. Mehmet Zafer Sabuncuoğlu, ${ }^{2}$ Dr. Recep Çetin ${ }^{1}$

${ }^{1}$ Süleyman Demirel Üniversitesi Tıp Fakültesi, Cerrahi Onkoloji Bilim Dalı, Isparta

${ }^{2}$ Süleyman Demirel Üniversitesi Tıp Fakültesi, Genel Cerrahi Anabilim Dalı, Isparta

Spontan ekstrahepatik safra yollarının perforasyonu, genellikle bebeklerde görülür. Erişkinlerde nadir görülmesine rağmen ölümcül safra peritonitiyle seyredebilir. Bundan dolayı akut karın tablosu ile başvuran bir hastaya zaman kaybetmeden karın ultrasonografisi ve bilgisayarlı tomografi gibi radyolojik görüntüleme yöntemleri ile ayırıcı tanı yapılmalıdır. Bu görüntüleme incelemelerinde safra taşı hastalığı ile birlikte perihepatik serbest sıvı veya koledoğun takip edilememesi durumunda ayırıı tanıda düşünülmelidir. Ciddi komplikasyonlarından korunmak için acil cerrahi girişim planlanmalıdır. Bu yazıda erişkin bir hastada spontan ortak hepatik kanal perforasyonuna bağlı gelişen nadir bir akut karın sebebini sunmayı amaçladık. Anahtar sözcükler: Akut karın; cerrahi; ortak hepatik kanal; spontan perforasyon.

Ulus Travma Acil Cerrahi Derg 2016;22(1):103-105 doi: 10.5505/tjtes.2015.95।42 